\title{
The Dehalogenases of a 2,2-Dichloropropionate-degrading Bacterium
}

\author{
By N. ALLISON, ${ }^{1} \uparrow$ A. J. SKINNER ${ }^{1 *}$ AND R. A. COOPER ${ }^{2}$ \\ ${ }^{1}$ Department of Life Sciences, Trent Polytechnic, Nottingham NGI 4BU, U.K. \\ ${ }^{2}$ Department of Biochemistry, School of Biological Sciences, University of Leicester, \\ Leicester LE1 7RH, U.K.
}

(Received 21 May 1982; revised 4 November 1982)

\begin{abstract}
A bacterium capable of utilizing the selective herbicide 2,2-dichloropropionate (2,2DCP; Dalapon) as sole source of carbon and energy was shown to possess inducible dehalogenase activity. Enzyme activity was also induced by numerous other haloalkanoic acids. Chlorinated compounds were generally better inducers of dehalogenase than the corresponding brominated compounds. Cell extracts of 2,2DCP-grown bacteria liberated free halide ion from several C-2 substituted alkanoic acids; C-3 and C-4 monosubstituted acids and halogenated acetamides were not attacked. Brominated compounds were dehalogenated more readily than the corresponding chlorinated compounds. Gel electrophoresis of cell extracts indicated the presence of at least two dehalogenases in 2,2DCP-grown bacteria. These were separable by ionexchange chromatography. Both partially purified dehalogenase activities had a fairly broad specificity, attacking several haloalkanoic acids in addition to 2,2DCP. Monohalogenated acetates were substrates for one of the dehalogenase activities but were potent inhibitors of the other. The two activities differed in their susceptibility to thiol-blocking reagents but had similar apparent molecular weights.
\end{abstract}

\section{INTRODUCTION}

Various micro-organisms are capable of degrading the selective herbicide 2,2-dichloropropionate (2,2DCP; Dalapon) in the soil (Foy, 1975). Some of these organisms are known to possess inducible dehalogenases which effect the hydrolytic removal of the substituent halogens from the herbicide, thus rendering it susceptible to further degradation (Jensen, 1957, 1960; Hirsch \& Alexander, 1960; Berry et al., 1979). Dehalogenases from micro-organisms capable of growth on, or in the presence of, halogenated acetates have been studied by Little \& Williams (1971), Goldman (1965) and Goldman et al. (1968). Similarly, Slater et al. (1979) examined the dehalogenase activity of a strain of Pseudomonas putida able to utilize 2-chloropropionate as carbon and energy source. Apart from the preliminary studies of Kearney et al. (1964), Slater et al. (1976) and Berry et al. (1979) very little is known of the properties of the dehalogenase activity synthesized by bacteria which can utilize 2,2DCP as sole source of carbon. Studies on the regulation of dehalogenase synthesis in organisms degrading haloalkanoic acids are essentially restricted to those of Goldman et al. (1968), Slater et al. (1979) and Berry et al. (1979). The present investigation describes the induction and properties of dehalogenases from a 2,2DCPdegrading bacterium.

\section{METHODS}

Organism. The 2,2DCP-degrading bacterium used in the present study has been tentatively identified as a fastgrowing species of Rhizobium (Berry et al., 1979). The organism was maintained on slopes of minimal agar containing $0 \cdot 2 \%(\mathrm{w} / \mathrm{v}) 2,2 \mathrm{DCP}$ and stored at $4{ }^{\circ} \mathrm{C}$.

† Present address: Department of Biochemistry, University of Glasgow, Glasgow G12 8QQ, U.K.

Abbreviation: 2,2DCP, 2,2-dichloropropionate (Dalapon). 
Growth conditions. Bacteria were grown in a mineral salts medium as described by Berry et al. (1979). When more than 1 litre of cells were required the organism was grown in a 4 litre fermenter (L.H. Engineering, Stoke Poges, Bucks. U.K.) at $30^{\circ} \mathrm{C}$ using an aeration rate of 1 litre air $\mathrm{min}^{-1}$ (1 medium) ${ }^{-1}$ and a stirring rate of 250 r.p.m. Growth was followed by measuring the absorbance of the culture at $680 \mathrm{~nm}$ using a Unicam SP 600 spectrophotometer.

Preparation of cell extracts. For dehalogenase assays, cell extracts containing 3 to $6 \mathrm{mg}$ bacterial protein $\mathrm{ml}^{-1}$ were prepared according to Berry et al. (1979), except that centrifugation of the sonicated cell suspension was at $38000 \mathrm{~g}$ for $15 \mathrm{~min}$.

Dehalogenase assavs. Dehalogenase activity was assessed at $30^{\circ} \mathrm{C}$ by measuring the rate of halide ion release from halogenated substrates in incubation mixtures containing $320 \mu \mathrm{mol}$ phosphate buffer $\mathrm{pH} 7 \cdot 2,0.5$ to $2.0 \mathrm{ml}$ cell extract (or enzyme preparation) and distilled water to a final volume of $6 \mathrm{ml}$. The reaction was initiated by the addition of substrate $(60$ to $540 \mu \mathrm{mol})$. Samples $(0 \cdot 1$ to $1.0 \mathrm{ml})$ were removed at appropriate intervals and assayed for halide ion using a Corning EEL (model 920) chloride meter. The instrument could be used to titrate accurately bromide and iodide ions, as well as chloride ions, after calibration with the appropriate standard solutions. Appropriate allowance was made for any spontaneous breakdown of halogenated substrates.

Dehalogenase activity could also be assayed, in the above incubation mixtures, by measuring the rate of pyruvate or glyoxylate formation from 2,2DCP or dichloroacetate, respectively, using 2,4-dinitrophenylhydrazine (Friedemann \& Haugen, 1943; Lewis \& Weinhouse, 1957). Dehalogenase specific activities are expressed as either nmol halide ion released or nmol oxoacid formed $\min ^{-1}$ ( $\mathrm{mg}$ protein $)^{-1}$.

Dehalogenase induction. Sterile solutions of haloalkanoic acids were added to shake flask cultures ( $100 \mathrm{ml})$ of bacteria, growing exponentially on $0 \cdot 4 \%(\mathrm{w} / \mathrm{v})$ lactate as sole carbon source, to give a final concentration of $0 \cdot 2 \%$ $(w / v)$. Following $16 \mathrm{~h}$ incubation with the given halogenated compound, bacteria were harvested and cell extracts prepared. These were assayed for dehalogenase activity immediately.

Thermal inactication of dehalogenase. Crude cell extracts were heated at $50{ }^{\circ} \mathrm{C}$ for periods of up to $30 \mathrm{~min}$. Samples were removed at appropriate time intervals, cooled to $4 \mathrm{C}$ and then assayed for dehalogenase activity using 2,2DCP, 2-chloropropionate, dichloroacetate and chloroacetate as substrates. Activities at each time interval are expressed as a percentage of the enzyme activity before exposure to the given temperature.

Polyacrylamide gel electrophoresis of cell extracts. Disc electrophoresis of crude extracts was performed using $7 \cdot 5^{\circ}{ }_{0}(\mathrm{w} / \mathrm{v})$ acrylamide gels in $38 \mathrm{~mm}$-Tris/glycine buffer $\mathrm{pH} 8.3$ according to Davis (1964). Extracts were diluted, if necessary, to give 2 to $3 \mathrm{mg}$ protein $\mathrm{ml}^{-1}$ in $10 \%(\mathrm{w} / \mathrm{v})$ sucrose and 15 to $30 \mu \mathrm{l}$ applied to each gel. Electrophoresis was conducted at room temperature with a current of $3 \mathrm{~mA}$ per gel tube. Dehalogenase activity was detected in gels by incubating separately with $150 \mathrm{~mm}-2,2 \mathrm{DCP}$, chloroacetate, dichloroacetate, trichloroacetate or 2chlorobutyrate at $30^{\circ} \mathrm{C}$ for $10 \mathrm{~min}$, followed by immersion in $0.5 \%(\mathrm{w} / \mathrm{v}) \mathrm{AgNO}_{3}$ solution for $15 \mathrm{~min}$. Chloride ion released from substrates at sites of dehalogenase activity caused a dense white precipitate of silver chloride within the gels. Alternatively, oxoacid formation, by dehalogenation of either 2,2DCP or dichloroacetate, was detected in gels by incubating with $0.02 \%(\mathrm{w} / \mathrm{v}) 2$,4-dinitrophenylhydrazine in $2 \mathrm{M}-\mathrm{HCl}$ for $5 \mathrm{~min}$ at $30 \mathrm{C}$ followed by immersion in $10 \%(\mathrm{w} / \mathrm{v}) \mathrm{NaOH}$. Brown-orange bands of 2,4-dinitrophenylhydrazone formed after 5 to $10 \mathrm{~min}$ in regions where dehalogenase activity was present.

Partial purification of dehalogenases. Bacteria (4 litres) grown on 2,2DCP were harvested in late exponential/ early stationary growth phase by centrifugation at $6000 \mathrm{~g}$ for $10 \mathrm{~min}$ and then washed once with $100 \mathrm{~mm}$ phosphate buffer, $\mathrm{pH} 7 \cdot 2$. Unless otherwise stated, all subsequent steps were performed at 4 C with EDTA $(1 \mathrm{~mm})$, dithiothreitol $(1 \mathrm{mM})$ and glycerol $(10 \%, \mathrm{w} / \mathrm{v})$ in all buffers. The washed organisms were resuspended in $100 \mathrm{~mm}$-phosphate buffer, $\mathrm{pH} 7.6(30 \mathrm{ml})$ and the suspension divided into two equal portions, each of which was sonicated in an MSE disintegrator $(100 \mathrm{~W})$ for $2 \mathrm{~min}$ in $30 \mathrm{~s}$ bursts, with $30 \mathrm{~s}$ intervals for cooling. The sonicates were pooled and centrifuged at $38000 \mathrm{~g}$ for $30 \mathrm{~min}$ to remove cell debris. Protein was estimated in the resultant supernatant and was in the range of 12 to $15 \mathrm{mg} \mathrm{ml}^{-1}$.

Finely powdered $\left(\mathrm{NH}_{4}\right)_{2} \mathrm{SO}_{4}\left[258 \mathrm{mg}(\mathrm{ml} \text { extract })^{-1}\right]$ was slowly added to $30 \mathrm{ml}$ cell extract to give $45 \%$ saturation. The protein solution was slowly stirred for $30 \mathrm{~min}$ prior to centrifugation at $38000 \mathrm{~g}$ for $30 \mathrm{~min}$ and the precipitate discarded. Further $\left(\mathrm{NH}_{4}\right)_{2} \mathrm{SO}_{+}\left(123 \mathrm{mg} \mathrm{ml}^{-1}\right)$ was added to the supernatant to yield $65 \%$ saturation. After the $\left(\mathrm{NH}_{4}\right)_{2} \mathrm{SO}_{4}$ had dissolved, the mixture was centrifuged, as above, and the pellet resuspended in $100 \mathrm{~mm}-$ phosphate buffer, $\mathrm{pH} 7.6(6.0 \mathrm{ml})$. The latter solution was dialysed for $16 \mathrm{~h}$ against $20 \mathrm{~mm}$-phosphate buffer, $\mathrm{pH} 7.6(200 \mathrm{ml})$.

A small volume of retentate (containing approximately $85 \mathrm{mg}$ protein) was applied to a column (internal dimensions $1.5 \times 50 \mathrm{~cm}$ ) of DEAE-cellulose (Whatman DE52). Unbound protein was removed by washing the column with one bed volume $(88 \mathrm{ml})$ of $20 \mathrm{~mm}$-phosphate buffer, $\mathrm{pH} 7 \cdot 6$. Bound protein was eluted using a linear concentration gradient of 20 to $120 \mathrm{~mm}$-phosphate buffer $\mathrm{pH} 7.6$ (total volume $500 \mathrm{ml}$ ) using a flow rate of $20 \mathrm{ml} \mathrm{h}^{-1}$. The effluent from the column was continuously monitored for protein by its absorbance at $280 \mathrm{~nm}$. Fractions were assayed for dehalogenase activity with 2,2DCP, 2-chloropropionate, dichloroacetate and chloroacetate as substrates. 
Fractions containing high activity were pooled and pipetted into washed dialysis bags. Concentration was effected by coating the outer surface with dry Sephadex G50 powder (coarse grade) to produce a 4- to 5-fold concentration.

Molecular neight estimation. Gel filtration chromatography was employed to estimate the molecular weight of partially purified dehalogenases. Fractions containing high dehalogenase activity were concentrated 5- to 6-fold by adding $\left(\mathrm{NH}_{4}\right)_{2} \mathrm{SO}_{4}$ to $80 \%$ saturation; the precipitated protein was redissolved in a small volume of $20 \mathrm{mM}$ phosphate buffer, $\mathrm{pH} 7.6$. Approximately $1.0 \mathrm{ml}$ of concentrated protein solution (containing 1.5 to $2.0 \mathrm{mg}$ protein) was applied to a column of Sephadex G200 (fine grade) of internal dimensions $1.5 \times 50 \mathrm{~cm}$ and eluted

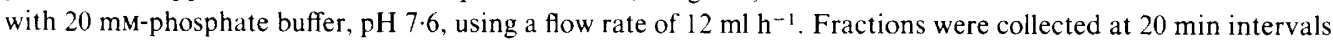
and assayed for dehalogenase activity using 2-chloropropionate as substrate to determine the elution volumes for the partialiy purified dehalogenases. Samples $\left(1.0 \mathrm{ml} ; 2 \mathrm{mg} \mathrm{ml}^{-1}\right.$ solutions) of standard proteins of known molecular weights (catalase, fibrinogen, bovine serum albumin, haemoglobin, trypsin and cytochrome $c$ ) were similarly applied to the same column. Protein peaks in the fractions were detected spectrophotometrically at $280 \mathrm{~nm}$ and the elution volume for each protein calculated. The molecular weights of the dehalogenases were calculated from a graph of $V_{\mathrm{e}} / V_{0}$ against $\log _{10}$ (molecular weight) for the marker proteins.

Kinetic and enzlme inhibition studies. A 100 -fold range of substrate concentrations was employed in the derivation of kinetic constants, all other parameters affecting enzyme activity remaining unchanged throughout. Double reciprocal plots were used to determine apparent Michaelis constants. Enzyme inhibition studies were conducted using partially purified dehalogenases. Enzyme solutions were adjusted to give 0.35 to $0.40 \mathrm{mg}$ protein $\mathrm{ml}^{-1}$ for these experiments; activity measured after 5 and $20 \mathrm{~min}$ preincubation with inhibitor was compared with activity in its absence.

Protein estimation. Protein was estimated in crude cell extracts by the Lowry method and in $\left(\mathrm{NH}_{4}\right)_{2} \mathrm{SO}_{4}$ fractions and column fractions by the method of Warburg \& Christian (1941). Crystalline bovine serum albumin was used as the standard.

Chemicals. The sodium salt of 2,2-dichloropropionic acid was obtained from Fluka AG Chemische Fabrik, CH9470 Buchs, Switzerland, as were 2-chlorobutyric, 2,3-dichloropropionic and dibromoacetic acids. 2Chloropropionic, 3-chloropropionic, 4-chlorobutyric, 2-bromopropionic and tribromoacetic acids were obtained from Aldrich Chemical Co. Ltd., Gillingham, Dorset. 2,3-Dibromopropionic, 4-bromobutyric and iodoacetic acids, chloroacetamide, iodoacetamide, chloramphenicol and 2,4-dichlorophenoxyacetic acid were obtained from Sigma. Chloroacetic. trichloroacetic, bromoacetic and 3-bromopropionic acids were obtained from BDH. 2,3Dibromobutyric acid was obtained from Koch Light. All chemicals were of the highest purity commercially available.

\section{RESULTS}

\section{Growth of the 2,2DCP-degrading bacterium}

From a wide range of compounds tested, 2,2DCP, 2-chloropropionate and 2-bromopropionate were the only haloalkanoic acids to support growth of the organism as sole carbon and energy source. The following halogenated compounds did not support growth of the isolate: 3-chloropropionate, 3-bromopropionate, chloroacetate, chloroacetamide, iodoacetate, iodoacetamide, bromoacetate, dichloroacetate, dibromoacetate, trichloroacetate, tribromoacetate, 2,3-dichloropropionate, 2,3-dibromopropionate, 2-chlorobutyrate, 4-chlorobutyrate, 4-bromobutyrate, 2,3-dibromobutyrate and 2,4-dichlorophenoxyacetate. Doubling times in shake-flask cultures at $30^{\circ} \mathrm{C}$ with $2,2 \mathrm{DCP}, 2$-chloropropionate and 2-bromopropionate were $11 \cdot 8,7 \cdot 0$ and $5 \cdot 0 \mathrm{~h}$ respectively. The organism grew on $2,2 \mathrm{DCP}$ at concentrations of up to $0.75 \%$ $(\mathrm{w} / \mathrm{v})$ but growth on either of the two monohalogenated propionates was inhibited when their concentrations exceeded $0.2 \%(\mathrm{w} / \mathrm{v})$. During growth on 2,2DCP in a 4 litre fermenter, the doubling time was somewhat greater, namely $14 \mathrm{~h}$ (Fig. 1). The organism liberated free chloride ion into the medium and, as a consequence of this dehalogenation reaction, the $\mathrm{pH}$ decreased (Fig. 1). Growth continued until all available covalently bound halogen had been released.

\section{Dehalogenase activity of cell extracts}

Cell extracts of 2,2DCP-grown bacteria liberated halide ion from a variety of 2-haloalkanoic acids (Table 1). Acids halogenated at other positions on the carbon chain, for example 3chloropropionate and 4-chlorobutyrate, were not attacked unless a 2-halogen substituent was also present. Brominated alkanoic acids were better substrates than the corresponding 


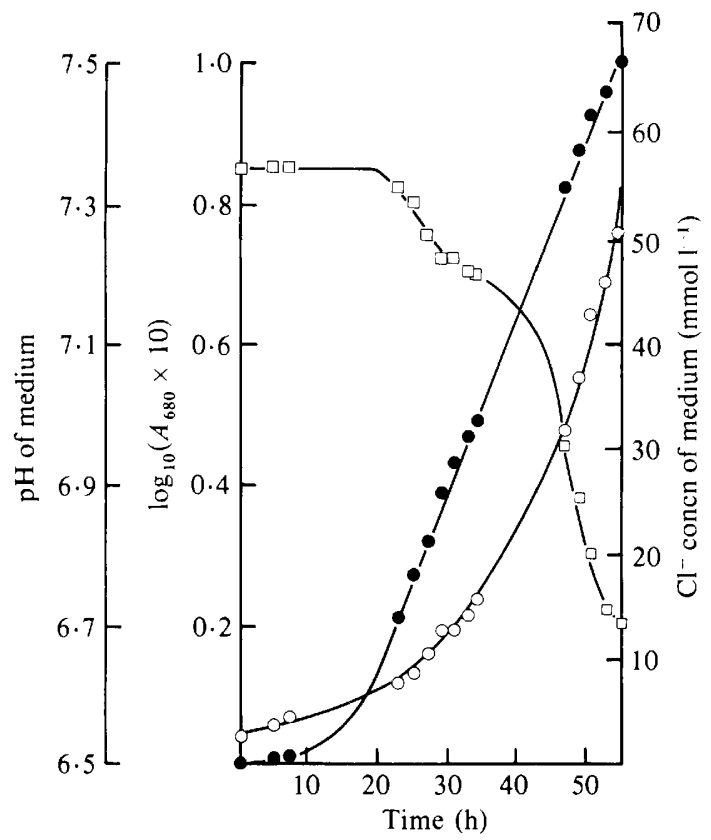

Fig. 1. Growth of the 2,2DCP-degrading bacterium. The organism was grown on 2,2DCP in a 4 litre fermenter as described in Methods., $\log _{10}\left(A_{680} \times 10\right) ; \square, \mathrm{pH}$ of medium; $\mathrm{O}, \mathrm{Cl}^{-}$concentration of medium.

Table 1. Halide ion release from halogenated compounds by cell extracts of 2,2DCP-grown bacteria

$\begin{array}{lcr}\text { Substrate } & \begin{array}{c}\text { Specific } \\ \text { activity* }\end{array} & \begin{array}{c}\text { Relative rate of } \\ \text { dehalogenation } \dagger\end{array} \\ \text { 2,2DCP } & 243 & 100 \\ \text { 2-Chloropropionate } & 753 & 310 \\ \text { 3-Chloropropionate } & 0 \ddagger & 0 \\ \text { 2,3-Dichloropropionate } & 535 & 220 \\ \text { Trichloroacetate } & 41 & 17 \\ \text { Dichloroacetate } & 140 & 58 \\ \text { Chloroacetate } & 632 & 260 \\ \text { Chloroacetamide } & 0 \ddagger & 0 \\ \text { 2-Chlorobutyrate } & 204 & 84 \\ \text { 4-Chlorobutyrate } & 0 \ddagger & 0 \\ \text { 2-Bromopropionate } & 3450 & 1420 \\ \text { 3-Bromopropionate } & 0 \ddagger & 0 \\ \text { Tribromoacetate } & 187 & 77 \\ \text { Dibromoacetate } & 2750 & 1130 \\ \text { Bromoacetate } & 7560 & 3110 \\ \text { 4-Bromobutyrate } & 0 \ddagger & 0 \\ \text { Iodoacetate } & 2620 & 1080 \\ \text { Iodoacetamide } & 0 \ddagger & 0 \\ \left.\quad * \text { Units: nmol halide ion released } \mathrm{min}^{-1} \text { (mg protein }\right)^{-1} . \\ \quad \dagger \text { Rate with 2,2DCP set at 100. }\end{array}$

chlorinated acids, specific activities being 4 to 20 times greater than those obtained with the corresponding chloroacids. Of all the compounds tested bromoacetate was dehalogenated most rapidly, whilst the best chlorinated substrate was 2-chloropropionate. Extracts dehalogenated 2,3-dichloropropionate at more than twice the rate seen with 2,2DCP (Table 1). Reliable dehalogenation rates could not be obtained with 2,3-dibromopropionate and 2,3-dibromobutyr- 
Table 2. Halide ion release from halogenated alkanoic acids by cell extracts of bacteria grown on various carbon sources

\begin{tabular}{|c|c|c|c|c|c|}
\hline \multirow[b]{2}{*}{ Carbon source(s) for growth } & \multirow[b]{2}{*}{$\begin{array}{l}\text { Specific } \\
\text { activity* }\end{array}$} & \multicolumn{4}{|c|}{ Relative rate of dehalogenation $\dagger$ using, as substrate: } \\
\hline & & $2,2 \mathrm{DCP}$ & $\begin{array}{l}\text { 2-Chloro- } \\
\text { propionate }\end{array}$ & $\begin{array}{l}\text { Dichloro- } \\
\text { acetate }\end{array}$ & $\begin{array}{l}\text { Chloro- } \\
\text { acetate }\end{array}$ \\
\hline $2,2 \mathrm{DCP}$ & 243 & 100 & 310 & 58 & 260 \\
\hline Lactate $+2,2 \mathrm{DCP}$ & 134 & 100 & 342 & 67 & 278 \\
\hline 2-Chloropropionate & 65 & 100 & 252 & 51 & 160 \\
\hline Lactate +2 -chloropropionate & 102 & 100 & 321 & 63 & 256 \\
\hline 2-Bromopropionate & 32 & 100 & NT & NT & $N T$ \\
\hline Lactate + 2-bromopropionate & 53 & 100 & NT & NT & NT \\
\hline Lactate + 2,3-dichloropropionate & 125 & 100 & 335 & 85 & 280 \\
\hline Lactate + dichloroacetate & 120 & 100 & 332 & 63 & 243 \\
\hline Lactate + dibromoacetate & 40 & 100 & NT & NT & NT \\
\hline Lactate + trichloroacetate & 109 & 100 & 245 & 50 & 238 \\
\hline Lactate + tribromoacetate & 60 & 100 & NT & NT & NT \\
\hline Lactate +2 -chlorobutyrate & 82 & 100 & 357 & 82 & 276 \\
\hline Lactate +3 -chloropropionate & 48 & 100 & 308 & 101 & 130 \\
\hline Lactate + 3-bromopropionate & 43 & 100 & NT & NT & NT \\
\hline
\end{tabular}

ate as substrates since dehalogenation of these compounds continued when samples from incubation mixtures were removed to $0{ }^{\circ} \mathrm{C}$ to stop the enzyme-mediated reaction. Chloroacetate and iodoacetate were both excellent substrates for dehalogenase in cell extracts, but chloroacetamide and iodoacetamide were not attacked. There was no removal of halogen from either 2,4-dichlorophenoxyacetate or chloramphenicol.

Berry et al. (1979) found that 2,2DCP was dehalogenated by cell extracts to yield pyruvate, two chloride ions being released per molecule of pyruvate formed. In the present study, similar stoichiometry was observed for the dehalogenation of dichloroacetate and dibromoacetate, the rate of glyoxylate formation being half the rate of halide ion release from these dihalogenated acids.

Using 2,2DCP as substrate no loss of dehalogenase activity occurred after storage of cell extracts at $4{ }^{\circ} \mathrm{C}$ for $24 \mathrm{~h}$. Storage for $24 \mathrm{~h}$ at $-20{ }^{\circ} \mathrm{C}$ resulted in an $18 \%$ decrease in enzyme activity and $11 \%$ of the initial dehalogenase activity was lost after $24 \mathrm{~h}$ at room temperature. Extracts incubated for $30 \mathrm{~min}$ at $50{ }^{\circ} \mathrm{C}$ rapidly lost dehalogenase activity when tested with 2,2DCP, 2-chloropropionate, dichloroacetate and chloroacetate as substrates. Activity against chloroacetate was lost more rapidly than activity against the other three substrates; after 5 min at $50{ }^{\circ} \mathrm{C}$ only $10 \%$ of the activity with chloroacetate remained, compared with $50 \%$ of the $2,2 \mathrm{DCP}$ activity. This suggests that more than one dehalogenase may be present.

\section{Induction of dehalogenase activity by haloalkanoic acids}

Bacteria grown on non-halogenated carbon sources, for example lactate, pyruvate and glucose, contained negligible dehalogenase activity (Berry et al., 1979). Significant dehalogenase activity was detectable $2 \mathrm{~h}$ after the addition of 2,2DCP to cultures growing exponentially on lactate as sole carbon source. A wide range of other haloalkanoic acids also induced dehalogenase activity in cultures growing on lactate (Table 2). The best inducers were 2,2DCP, 2-chloropropionate, dichloroacetate, trichloroacetate and 2,3-dichloropropionate, all of which yielded specific activities greater than $100 \mathrm{nmol} \mathrm{Cl}^{-}$released $\mathrm{min}^{-1}$ (mg protein) ${ }^{-1}$ using $2,2 \mathrm{DCP}$ as substrate. Brominated compounds were generally poorer inducers of dehalogenase than the corresponding chlorinated compounds. For example, the specific activity of dehalogenase in extracts prepared from bacteria grown on lactate plus dibromoacetate was only one-third of that measured in extracts of cells exposed to an equivalent concentration of 
dichloroacetate (Table 2). Monohalogenated acetates were potent inhibitors of growth on lactate and, together with 4-chlorobutyrate, did not induce dehalogenase activity in the organism.

Relative rates of dehalogenation were measured using extracts prepared from bacteria grown under a variety of inducing conditions (Table 2). Extracts from bacteria grown on 2,2DCP, and on lactate in the presence of 2,2DCP, 2-chloropropionate or dichloroacetate, exhibited similar relative rates of dehalogenase activity. Surprisingly, the relative rates with 2 -chloropropionate and chloroacetate as substrates were significantly lower in extracts of bacteria grown on 2chloropropionate as sole carbon source. 3-Chloropropionate-induced dehalogenase activity was different from that induced by the other compounds tested. With chloroacetate and dichloroacetate as substrates the relative rates were half and nearly double, respectively, the corresponding relative rates observed in extracts of 2,2DCP-grown cells (Table 2). This is further evidence for the existence of more than one dehalogenase activity in this bacterium.

\section{Polyacrylamide gel electrophoresis of cell extracts}

Extracts of 2,2DCP-grown bacteria were subjected to electrophoresis on polyacrylamide gels. The gels were then incubated with various substrates and stained for either chloride ion or $\alpha$ oxoacid. Two bands of dehalogenase activity were found, the dimensions and density of which varied according to the substrate with which the particular gel had been incubated (Fig. $2 a$ ). Two dissimilar bands were observed in gels incubated with 2,2DCP and stained for either chloride ion or pyruvate. In both cases the upper and least electrophoretically mobile band was thinner and less densely stained than the lower band. Gels incubated with chloroacetate, trichloroacetate or 2-chlorobutyrate showed a similar pattern to the above when stained for chloride ion. The upper band in gels exposed to chloroacetate and trichloroacetate was thinner and less densely stained than the corresponding bands in gels incubated with either 2,2DCP or 2chlorobutyrate (Fig. 2a). The bands in gels incubated with dichloroacetate differed markedly from those obtained with the other substrates, the upper band being thicker and more densely stained than the lower. Electrophoresis of extracts prepared from cells grown on lactate plus either 2-chlorobutyrate or dichloroacetate resulted in a similar distribution of dehalogenase activity to that obtained using extracts of 2,2DCP-grown bacteria. Using extracts of 2chloropropionate-grown cells, differences in size and density between the two bands formed with 2,2DCP as substrate were less well marked. Extracts of cells grown on lactate plus 3-chloropropionate gave markedly different staining patterns from the above. Gels incubated with either 2,2DCP or dichloroacetate possessed only one band of dehalogenase activity which occupied a similar position to the upper band found in extracts of 2,2DCP-grown bacteria (Fig. $2 b$ ). With chloroacetate as substrate, two bands were observed, the upper being much broader and denser than the lower.

\section{Partial purification and properties of dehalogenases from 2,2DCP-grown bacteria}

Further evidence for more than one dehalogenase was obtained when the partial purification of dehalogenase activity from bacteria grown on 2,2DCP was undertaken. Using $\left(\mathrm{NH}_{4}\right)_{2} \mathrm{SO}_{4}$ fractionation, followed by ion-exchange chromatography, it was possible to separate two dehalogenase activities, as previously seen on polyacrylamide gels.

An $\left(\mathrm{NH}_{4}\right)_{2} \mathrm{SO}_{4}$ fraction precipitating between $45 \%$ and $65 \%$ saturation contained approximately $70 \%$ of the original dehalogenase activity and had a specific activity of $354 \mathrm{nmol}$ $\mathrm{Cl}^{-}$released $\mathrm{min}^{-1}$ (mg protein) ${ }^{-1}$, using 2,2DCP as substrate. Relative rates of dehalogenation obtained for this fraction were $100: 41: 206: 240$ with $2,2 \mathrm{DCP}$, dichloroacetate, 2-chloropropionate and chloroacetate respectively.

Ion-exchange chromatography of the dialysed $\left(\mathrm{NH}_{4}\right)_{2} \mathrm{SO}_{4}$ fraction gave two peaks of dehalogenase activity (Fig. 3). The first peak (peak I) showed significant activity towards 2,2DCP, 2-chloropropionate and dichloroacetate but negligible activity towards chloroacetate. The second peak (peak II) showed considerable activity towards all of these substrates. More than $95 \%$ of the dehalogenase activity was recovered in the fractions from ion-exchange chromatography, approximately $80 \%$ residing in peak II fractions. There was no detectable loss 


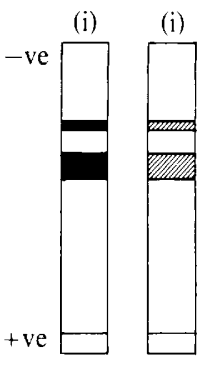

(a)
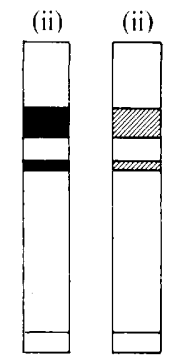
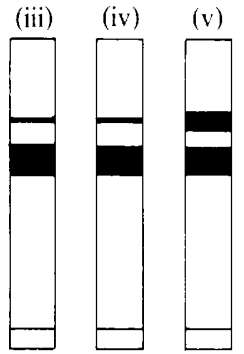

(b)
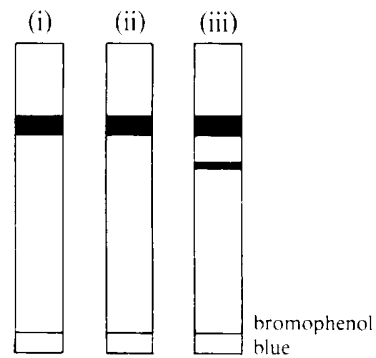

Fig. 2. Distribution of dehalogenase activity after polyacrylamide gel electrophoresis and staining with either $\mathrm{AgNO}_{3}$ or 2,4-dinitrophenylhydrazine. Solid areas represent bands of silver chloride, hatched areas represent bands of 2,4-dinitrophenylhydrazone. Electrophoresis was carried out as described in Methods, using cell extracts of bacteria grown on either 2,2DCP $(a)$ or lactate plus 3-chloropropionate (b). Gels were incubated with 2,2DCP (i), dichloroacetate (ii), chloroacetate (iii), trichloroacetate (iv) or 2-chlorobutyrate (v) as substrates.

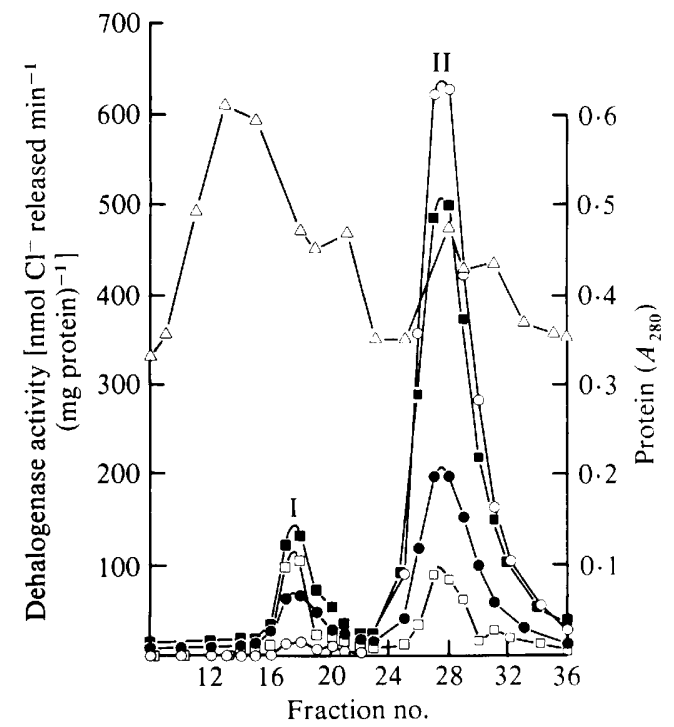

Fig. 3. Separation of dehalogenases by DEAE-cellulose chromatography. An $\left(\mathrm{NH}_{4}\right)_{2} \mathrm{SO}_{4}$ fraction obtained from extracts of 2,2DCP-grown bacteria was applied to a column of DEAE-cellulose as described in Methods. Fractions were assayed for protein $(\triangle)$ and dehalogenase activity using, as substrates, 2,2DCP ( ), 2-chloropropionate $(\square)$, dichloroacetate $(\square)$ and chloroacetate $(\bigcirc)$.

of dehalogenase activity in the pooled fractions during prolonged storage at $-20{ }^{\circ} \mathrm{C}$. Polyacrylamide gel electrophoresis of concentrated peak fractions demonstrated that peaks I and II represented, respectively, the upper and lower activity bands obtained after electrophoresis of crude cell extracts. However, following electrophoresis of Peak I fractions, no band was present in gels incubated with chloroacetate although activity was clearly visible in gels incubated with either 2,2DCP or dichloroacetate.

Concentrated fractions from ion-exchange chromatography were assayed for dehalogenase activity with a wide variety of haloalkanoic acids (Table 3). Dehalogenase in peak I showed negligible activity towards trichloroacetate, tribromoacetate and the three monohaloacetates whereas the peak II activity attacked all of these compounds. Dibromoacetate, 2bromopropionate, 2-chloropropionate and 2,3-dichloropropionate were dehalogenated more rapidly than 2,2DCP by both activities. With the exception of dichloroacetate, dibromoacetate and 2,3-dichloropropionate, relative rates of dehalogenation obtained with peak II were 
Table 3. Halide ion release from halogenated compounds by partially purified dehalogenases from 2,2DCP-grown bacteria

\begin{tabular}{|c|c|c|c|c|}
\hline \multirow[b]{2}{*}{ Substrate } & \multicolumn{2}{|c|}{ Peak I } & \multicolumn{2}{|c|}{ Peak II } \\
\hline & $\begin{array}{l}\text { Specific } \\
\text { activity* }\end{array}$ & $\begin{array}{c}\text { Relative } \\
\text { rate of } \\
\text { dehalogenation }+\end{array}$ & $\begin{array}{l}\text { Specific } \\
\text { activity* }\end{array}$ & $\begin{array}{c}\text { Relative } \\
\text { rate of } \\
\text { dehalogenation }+\end{array}$ \\
\hline $2,2 \mathrm{DCP}$ & 427 & 100 & 1890 & 100 \\
\hline 2-Chloropropionate & 773 & 181 & 4690 & 248 \\
\hline 2.3-Dichloropropionate & 1200 & 280 & 2460 & 130 \\
\hline Trichloroacetate & $0 \ddagger$ & 0 & 510 & 27 \\
\hline Dichloroacetate & $470^{+}$ & 110 & 680 & 36 \\
\hline Chloroacetate & $0 \ddagger$ & 0 & 6090 & 322 \\
\hline 2-Chlorobutyrate & $273^{+}$ & 64 & 2100 & 111 \\
\hline 2-Bromopropionate & 901 & 211 & 25000 & 1322 \\
\hline Tribromoacetate & $0_{+}^{+}$ & 0 & 2080 & 110 \\
\hline Dibromoacetate & $3500^{\circ}$ & 820 & 9090 & 481 \\
\hline Bromoacetate & $0_{+}^{+}$ & 0 & 52700 & 2790 \\
\hline Iodoacetate & $0 \ddagger$ & 0 & 13100 & 693 \\
\hline & $\begin{array}{l}\text { nmol hal } \\
\text { ith } 2,2 \mathrm{D} \\
y \text { below }\end{array}$ & $\begin{array}{l}\text { released } \mathrm{min}^{-} \\
\text {at } 100 \text {. } \\
\text { f detection. }\end{array}$ & $(e i n)^{-1}$ & \\
\hline
\end{tabular}

Table 4. Apparent Michaelis constants for various substrates, using cell extracts and partially purified dehalogenases from 2,2DCP-grown bacteria

\begin{tabular}{lccc} 
& \multicolumn{3}{c}{$\begin{array}{c}\text { Apparent Michaelis constant (mM) } \\
\text { using dehalogenase in: }\end{array}$} \\
\cline { 2 - 4 } Substrate & Cell extracts & Peak I & Peak II \\
2,2DCP & $1.95^{*}$ & $3 \cdot 4$ & $0 \cdot 47$ \\
2-Chloropropionate & $3.8^{*}$ & $0 \cdot 94$ & $4 \cdot 7$ \\
2-Bromopropionate & $7 \cdot 0$ & $\mathrm{NT}$ & $\mathrm{NT}$ \\
Chloroacetate & $16 \cdot 4^{*}$ & $\mathrm{~ns}$ & 26 \\
Bromoacetate & 52 & $\mathrm{~ns}$ & $\mathrm{NT}$ \\
Dichloroacetate & $1.69^{*}$ & $0 \cdot 31$ & $1 \cdot 4$ \\
Dibromoacetate & 4.6 & $0 \cdot 19$ & $5 \cdot 1$
\end{tabular}

NT, Not tested; ns, not a substrate.

* From Berry et al. (1979).

significantly greater than the corresponding rates with Peak I (Table 3). No activity was observed with 3- or 4-monohalogenated acids, iodoacetamide or chloroacetamide.

Apparent Michaelis constants for 2-chloropropionate, dichloroacetate and dibromoacetate using peak II were higher than the corresponding values determined with peak I (Table 4). For 2,2DCP the converse was true, the $K_{\mathrm{m}}$ using peak I being seven times that obtained with peak II. The monohaloacetates, which were good substrates for peak II dehalogenase, proved to be potent inhibitors of peak I activity; 5 min preincubation with these compounds at concentrations of $10 \mathrm{mM}$ caused total inhibition, using 2,2DCP as substrate. Similar preincubation of peak II dehalogenase with 3-bromopropionate $(10 \mathrm{mM})$ caused a $75 \%$ decrease in activity with either 2,2DCP or 2-chloropropionate as substrate. Neither dehalogenase activity was inhibited by $10 \mathrm{~mm}$-3-chloropropionate or $10 \mathrm{mM}$-chloroacetamide.

The partially purified dehalogenases differed substantially in their susceptibility to inactivation by thiol-blocking reagents (Table 5). Almost total inhibition of peak II activity occurred after 5 min incubation with $N$-ethylmaleimide. Incubation of peak I with this inhibitor for $5 \mathrm{~min}$ caused negligible loss of activity but $52 \%$ was lost after 20 min exposure. Peak II dehalogenase was also more susceptible than peak I to inhibition by iodoacetamide. Only slight inhibition of peak II dehalogenase was observed with $p$-chloromercuriphenylsulphonate whilst $22 \%$ of peak I activity was lost after 5 min exposure (Table 5 ). 
Table 5. Effect of thiol-blocking reagents upon the activity of partially purified dehalogenases

\begin{tabular}{|c|c|c|c|}
\hline \multirow[b]{2}{*}{ Inhibitor } & \multirow{2}{*}{$\begin{array}{c}\text { Incubation } \\
\text { time } \\
\text { (min) }\end{array}$} & \multicolumn{2}{|c|}{$\begin{array}{l}\text { Percentage } \\
\text { inhibition of : }\end{array}$} \\
\hline & & Peak I* & Peak II* \\
\hline \multirow[t]{2}{*}{$N$-Ethylmaleimide (1 mM) } & 5 & 3 & 97 \\
\hline & 20 & 52 & 100 \\
\hline \multirow{2}{*}{$p$-Chloromercuriphenylsulphonate $(0.01 \mathrm{~mm})$} & 5 & 22 & 2 \\
\hline & 20 & 29 & 8 \\
\hline \multirow[t]{2}{*}{ Iodoacetate $(10 \mathrm{~mm})$} & 5 & 100 & S \\
\hline & 20 & 100 & S \\
\hline \multirow[t]{2}{*}{ Iodoacetamide (10 mM) } & 5 & 2 & 62 \\
\hline & 20 & 15 & 91 \\
\hline
\end{tabular}

S, a substrate.

* Activities measured by following the rate of pyruvate formation from 2,2DCP.

Gel filtration of a dialysed $\left(\mathrm{NH}_{4}\right)_{2} \mathrm{SO}_{4}$ fraction using Sephadex $\mathrm{G} 200$ failed to separate two dehalogenases. The reason for this became apparent when concentrated fractions from ionexchange chromatography were subjected to gel filtration. The approximate molecular weights of dehalogenase in peaks I and II were found to be 93000 and 110000 , respectively.

\section{DISCUSSION}

The present study has examined in some detail the dehalogenase activities of a 2,2DCPutilizing bacterium. Knowledge of the initial stages in the degradation of this selective herbicide had previously been confined to the brief reports by Kearney et al. (1964), Slater et al. (1976) and Berry et al. (1979). These authors showed that cell extracts of 2,2DCP-grown bacteria exhibited dehalogenase activity with 2,2DCP and a few other chlorinated compounds. The bacterium used in the present investigation possesses at least two dehalogenase activities when grown on, or in the presence of, 2,2DCP and several other haloalkanoic acids, including a number of brominated compounds. The possibility that more than one dehalogenase resides in one, or both, activity peaks cannot be disregarded until further purification procedures have been undertaken.

The two partially purified dehalogenase activities resemble each other in several respects. For example both have a fairly broad specificity, attacking various haloalkanoic acids in addition to $2,2 \mathrm{DCP}$. Activity only occurs when one or more halogen atoms are present at the C-2 position. The dehalogenases from chloroacetate-degrading bacteria are similar in this respect (Davies \& Evans, 1962; Goldman, 1965; Little \& Williams, 1971) but the dehalogenase from a 2chloropropionate-utilizing bacterium exhibited very slight activity with 3-chloropropionate (Slater et al., 1979). Several brominated alkanoic acids were dehalogenated by both enzymes and, somewhat surprisingly, all proved to be much better substrates than the corresponding chlorinated acids. This was most noticeable for peak II activity, as dehalogenase in peak I did not attack mono- or tri-halogenated acetates. Dehalogenases from 2,2DCP-utilizing bacteria have not previously been reported to attack brominated compounds. The dehalogenase from a chloroacetate-utilizing bacterium was active with bromoacetate (Little \& Williams, 1971) but this is one of the few reports of a dehalogenase acting on brominated alkanoic acids. Some micro-organisms are known to use brominated compounds as sole sources of carbon and energy but their dehalogenases have not been studied.

Although both dehalogenase activities attacked several haloalkanoic acids, the substrate specificities differed considerably. In general, the best substrates for peak I dehalogenase activity were those with two halogen substituents and/or three carbon atoms. However, peak II dehalogenase activity was greatest with substrates possessing two carbon atoms and/or one halogen substituent. Compounds having several halogen substituents and/or a long carbon chain are presumably less able to gain access to the active site of peak II dehalogenase than are 
short-chain, monosubstituted compounds. Although the partially purified peak I dehalogenase did not exhibit any activity with monohaloacetates, electrophoresis of crude cell extracts revealed two bands of dehalogenase activity with chloroacetate. As the uppermost of these bands (peak I dehalogenase) was less dense and thinner than the lower, it is possible that this enzyme exhibits very slight activity with chloroacetate but that this is too low to be detected by the assay procedure. It is also possible that cell extracts of 2,2DCP-grown bacteria contain a small amount of a third dehalogenase, with slight activity against chloroacetate, which is lost during the purification procedure.

It was envisaged that at least one of the dehalogenase activities would be sensitive to thiolblocking reagents, as dithiothreitol was required during the enzyme purification procedure in order to prevent massive loss of dehalogenase activity. Peak II dehalogenase activity proved to be far more susceptible to inhibition by $N$-ethylmaleimide and iodoacetamide than peak I dehalogenase. These results indicate that peak II dehalogenase contains one or more highly reactive thiol groups which are essential for enzyme activity. It is unlikely that the inhibition of peak I dehalogenase by iodoacetate and bromoacetate is primarily due to their alkylating properties as the other thiol-blocking agents had little effect on the enzyme over short periods. Moreover, chloroacetate, which was also a potent inhibitor of peak I dehalogenase, does not have any appreciable alkylating properties (Webb, 1966). The monohaloacetates may inhibit dehalogenase by binding to the active site of the enzyme. By comparison, peak II dehalogenase was not inhibited by the monohaloacetates, even at high concentrations; in fact they were amongst the best substrates for this enzyme. Dehalogenases from other bacteria differ in their sensitivity to thiol-blocking reagents. For example, the dehalogenase from a fluoroacetatedegrading pseudomonad was extremely sensitive to inhibition by these compounds (Goldman, 1965 ) whilst the enzyme from a chloroacetate-degrading pseudomonad was insensitive to $\mathrm{N}$ ethylmaleimide and iodoacetate (Little \& Williams, 1971).

Most compounds that were dehalogenated by cell extracts were also found to be inducers of dehalogenase synthesis. In general, the best substrates were either poor inducers or did not induce any detectable dehalogenase. 2,2DCP proved to be the best inducer, possibly because the bacterium was selected from an enrichment culture with this compound as sole source of carbon. The relative amounts of the dehalogenases in a culture will depend upon the substance used as an inducer. From a study of the relative rates of halide ion release from four substrates and the electrophoresis experiments it appears that most, if not all, inducers caused two dehalogenases to be synthesized.

After polyacrylamide gel electrophoresis, extracts of bacteria grown in the presence of 3chloropropionate exhibited two bands of dehalogenase activity with chloroacetate as substrate. Although the positions of the bands were similar to those found in extracts of 2,2DCP-grown bacteria, the uppermost band was much broader than the lower. It therefore appears that 3chloropropionate, unlike 2,2DCP, induces much more of peak I dehalogenase than peak II dehalogenase. Alternatively, 3-chloropropionate may induce one or more dehalogenases different from those present in 2,2DCP-grown bacteria. This is a distinct possibility, especially as the partially purified peak I dehalogenase has little or no activity towards chloroacetate. Clearly there is a need to study in detail the properties of the dehalogenases from bacteria grown in the presence of 3-chloropropionate and compare them with those obtained from 2,2DCPgrown cells.

For a haloalkanoic acid to be utilized as sole source of carbon and energy it is probable that the compound will first enter the bacterium. It must then induce the synthesis of, and act as substrate for, one or both dehalogenases. Finally the organic product(s) of the dehalogenation reaction must be readily channelled into the central metabolic routes of the cell in order to provide energy and intermediates for biosynthesis. Of the 21 compounds examined, only 2,2DCP, 2-chloropropionate and 2-bromopropionate satisfied all of these criteria. 2,2DCP is converted to pyruvate (Berry et al., 1979) whilst 2-chloropropionate and 2-bromopropionate are presumably dehalogenated to give lactate (Goldman, 1972). Both pyruvate and lactate support good growth of the isolate, doubling times being 3.8 and $3.5 \mathrm{~h}$ respectively (Berry et al., 1979). Dichloroacetate and dibromoacetate induce dehalogenase synthesis and therefore probably 
enter the bacterial cell. In addition, these two compounds were substrates for both dehalogenase activities. However, they do not support growth of the isolate, presumably because their dehalogenation product (glyoxylate) cannot be utilized as sole carbon source by this bacterium (Berry et al., 1979). Similarly, 2,3-dichloropropionate, 2-chlorobutyrate, trichloroacetate and tribromoacetate are inducers of, and substrates for, at least one of the dehalogenases. The nature of their dehalogenation products is not known but it is assumed that they cannot be assimilated by the bacterium.

The present study has shown that a bacterium capable of growth on 2,2DCP can synthesize at least two distinct dehalogenases when grown in the presence of this compound and several other haloalkanoic acids. It is difficult to envisage why the organism synthesizes more than one dehalogenase, especially as the only halogenated compounds which support growth are substrates for, and inducers of, both enzymes. Pseudomonads grown on dichloroacetate and 2chloropropionate are known to synthesize two or more dehalogenases (Goldman et al., 1968; Weightman et al., 1979; Hardman \& Slater, 1981) and the occurrence of more than one dehalogenase in micro-organisms may be more widespread than is currently thought. The reasons for the multiplicity of these enzymes will only be forthcoming when we understand more about their properties and the regulation of their synthesis.

\section{REFERENCES}

Berry, E. K. M., Allison, N., Skinner, A. J. \& CoOper, R. A. (1979). Degradation of the selective herbicide 2,2-dichloropropionate (Dalapon) by a soil bacterium. Journal of General Microbiology 110, 3945.

Davies, J. I. \& Evans, W. C. (1962). Elimination of halide ions from aliphatic halogen-substituted organic acids by an enzyme preparation from Pseudomonas dehalogenans. Biochemical Journal 82, 50P$51 \mathrm{P}$.

DAvis, B. J. (1964). Disc electrophoresis. Method and application to human serum proteins. Annals of the New York Academy of Science 121, $404-427$.

Foy, C. L. (1975). The chlorinated aliphatic acids. In Herbicides - Chemistry, Degradation and Mode of Action, vol. 1, pp. $399-452$. Edited by P. C. Kearney \& D. D. Kaufman. New York: Marcel Dekker.

Friedemann, T. E. \& Haugen, G. E. (1943). Pyruvic acid. II. The determination of keto-acids in blood and urine. Journal of Biological Chemistry 147, 415 422 .

Goldman, P. (1965). The enzymatic cleavage of the carbon-fluorine bond in fluoroacetate. Journal of Biological Chemistry 240, 3434-3438.

Goldman, P. (1972). Enzymology of carbon-halogen bonds. In Degradation of Synthetic Organic Molecules in the Biosphere, pp. 147-165. Washington: National Academy of Sciences.

Goldman, P., Milne, G. W. A. \& Keister, D. B. (1968). Carbon-fluorine bond cleavage. III. Studies on bacterial halidohydrolases. Journal of Biological Chemistry 243, 428-434.

Hardman, D. J. \& Slater, J. H. (1981). Dehalogenases in soil bacteria. Journal of General Microbiolog. 123, $117-128$

Hirsch. P. \& Alexander, M. (1960). Microbial decomposition of halogenated propionic and acetic acids. Canadian Journal of Microbiology 6, 241-249.

JENSEN, H. L. (1957). Decomposition of chlorosubstituted aliphatic acids by soil bacteria. Canadian Journal of Microbiology 3, 151-164.

Jensen, H. L. (1960). Decomposition of chloroacetates and chloropropionates by bacteria. Acta agriculturae scandinatica 10, 83-103.

Kearney, P. C., Kaufman, D. D. \& Beall, M. L. (1964). Enzymic dehalogenation of 2,2-dichloropropionate. Biochemical and Biophysical Research Communications 14, 29-33.

Lewis, K. F. \& Weinhouse, S. (1957). Determination of glycolic, glyoxylic and oxalic acids. Methods in Enzlmology 3, 269-276.

Little, M. \& Williams, P. A. (1971). A bacterial halidohydrolase; its purification, some properties and its modification by specific amino acid reagents. European Journal of Biochemistry 21, 99-109.

Slater, J. H., Weightman, A. J., Senior, E. \& Bull, A. T. (1976). The dehalogenase from Pseudomonas putida. Society for General Microbiology Proceedings 4. $39-40$.

Slater, J. H., Lovatt, D., Weightman, A. J., Senior, E. \& Bull, A. T. (1979). The growth of Pseudomonas putida on chlorinated aliphatic acids and its dehalogenase activity. Journal of General Microbiology 114 , $125-136$.

Warburg, O. \& Christian, W. (1941). Isolierung und Kristallisation des Gärungsferments Enolase. Biochemische Zeitschrift 310, 384-421.

WEBB, J. L. (1966). Iodoacetate and iodoacetamide. In Enzlme and Metabolic Inhibitors, vol. 3, pp. 1-283. London: Academic Press.

Wejghtman, A. J.. Slater, J. H. \& Bull, A. T. (1979). The partial purification of two dehalogenases from Pseudomonas putida PP3. FEMS Microbiology Letters 6, 231-234. 